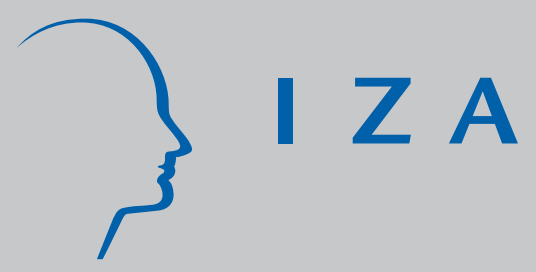

IZA DP No. 880

Employment Protection and Product Market Regulation

Winfried Koeniger

Andrea Vindigni

October 2003 


\title{
Employment Protection and Product Market Regulation
}

\author{
Winfried Koeniger \\ IZA Bonn
}

\author{
Andrea Vindigni \\ IIES, Stockholm University \\ and IZA Bonn
}

\section{Discussion Paper No. 880 \\ October 2003}

\author{
IZA \\ P.O. Box 7240 \\ D-53072 Bonn \\ Germany \\ Tel.: +49-228-3894-0 \\ Fax: +49-228-3894-210 \\ Email: iza@iza.org
}

This Discussion Paper is issued within the framework of IZA's research area Internationalization of Labor Markets. Any opinions expressed here are those of the author(s) and not those of the institute. Research disseminated by IZA may include views on policy, but the institute itself takes no institutional policy positions.

The Institute for the Study of Labor (IZA) in Bonn is a local and virtual international research center and a place of communication between science, politics and business. IZA is an independent, nonprofit limited liability company (Gesellschaft mit beschränkter Haftung) supported by Deutsche Post World Net. The center is associated with the University of Bonn and offers a stimulating research environment through its research networks, research support, and visitors and doctoral programs. IZA engages in (i) original and internationally competitive research in all fields of labor economics, (ii) development of policy concepts, and (iii) dissemination of research results and concepts to the interested public. The current research program deals with (1) mobility and flexibility of labor, (2) internationalization of labor markets, (3) welfare state and labor market, (4) labor markets in transition countries, (5) the future of labor, (6) evaluation of labor market policies and projects and (7) general labor economics.

IZA Discussion Papers often represent preliminary work and are circulated to encourage discussion. Citation of such a paper should account for its provisional character. A revised version may be available on the IZA website (www.iza.org) or directly from the author. 
IZA Discussion Paper No. 880

October 2003

\section{ABSTRACT}

\section{Employment Protection and Product Market Regulation*}

Product market regulation and employment protection are highly correlated across OECD countries. Using an augmented model of monopolistic competition we show why in countries with more regulated product markets, incumbent workers prefer to protect jobs relatively more. Product market regulation increases the scope for employment protection because firms can bear the cost of employment protection more easily and still break even. Moreover, product market regulation decreases employment so that the workers' outside option becomes relatively worse. This increases the incentive to protect the job.

JEL Classification: J63, J65, L16

Keywords: $\quad$ collective dismissal cost, political economy

Corresponding author:

Winfried Koeniger

IZA

P.O. Box 7240

53072 Bonn

Germany

Tel.: +49 2283894512

Fax: +492283894510

Email: koeniger@iza.org

* We thank Torben Andersen, Giuseppe Bertola, Gilles Saint-Paul, Dennis Snower, seminar participants at the CFS-ECB joint lunchtime seminar, Tilburg University, WZB and an IZA brown-bag lunch for very helpful comments. 


\section{Introduction}

Interactions between labor and product markets have received considerable attention in recent years. It is crucial to analyze such interactions and their effect on economic performance in order to understand why both types of regulation vary substantially across OECD countries and tend to be positively correlated (see, e.g., Nicoletti et al. (2001)). In Figure 1 we replicate the positive correlation between product market regulation (PMR) and employment protection legislation (EPL) in OECD countries. We use summary indicators for the 90s which are reported in Nicoletti et al. (1999). The correlation is .72 and highly significant. Whereas Anglo-Saxon countries have flexible labor markets and deregulated product markets the opposite is the case for continental European countries. From a theoretical perspective it is interesting to investigate why the policy mix implies either no distortions or distortions in both labor and product markets. A priori one might expect that adding one distortion would decrease the desire for adding another distortion unless there are substantial complementarities between the two types of regulation. Moreover, interactions between labor and product market policies are of particular interest for countries attempting policy reform (see, e.g., Orszag and Snower (1998) on the importance of economic and political complementarities for policy reform). Indeed, we show why it is particularly difficult to deregulate labor markets if product markets are heavily regulated. We focus on the interests of incumbent workers because they are the only ones who benefit from employment protection. Hence, it is an essential starting point to investigate how labor and product market regulation interact for this group of the population.

In the model product market regulation is captured by entry costs where we take the regulation of product markets as exogenously determined by the judicial system (see Djankov et al. (2002), Table 7, for the association of judicial systems with entry regulation). Instead of arguing that the judicial system determines regulation both in the product and labor market (see Botero et al. (2003) for the effect of judicial systems on labor market regulation) we investigate how product market regulation endogenously changes the incentives for the regulation of labor markets. We 


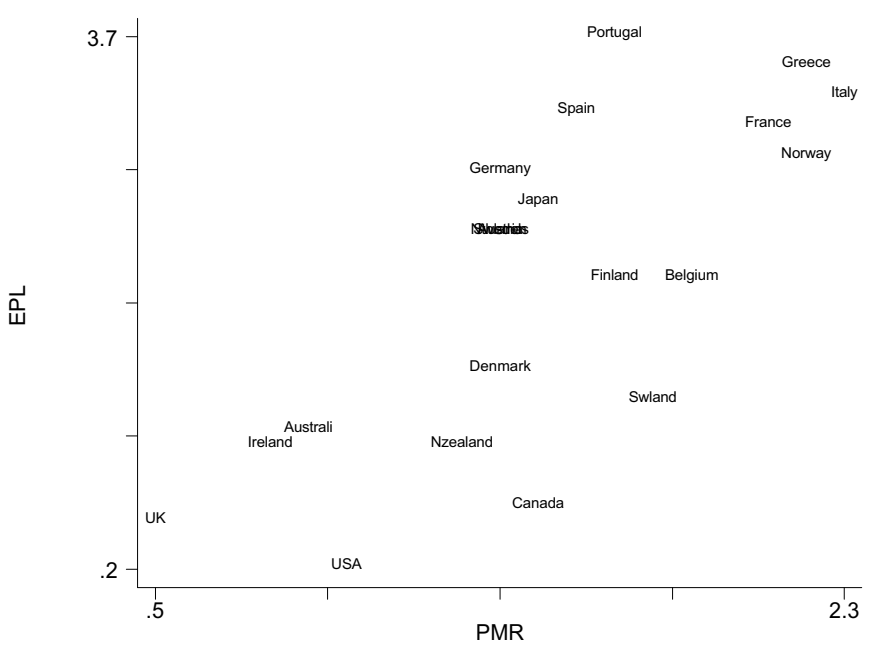

Figure 1: Product Market Regulation (PMR) and Employment Protection Legislation (EPL) in OECD countries. Source: Nicoletti et al. (1999), Tables A3.7 and A3.11. The indicator on product market regulation summarizes state control, barriers to entrepreneurship, barriers to trade and investment, and economic and administrative regulation. The indicator on employment protection summarizes regulation for regular and temporary contracts. 
focus on EPL which we assume to imply wasteful costs so that EPL feeds back into the structure of the product market: in the model, EPL decreases the equilibrium number of firms and thus has a negative effect on competition in the product market.

The product market is modelled similar to Blanchard and Giavazzi (2003). In the labor market workers compete for jobs ex ante but appropriate rents ex post. In order to derive analytic results we assume that each firm employs only one worker. This implies that firing costs have to be interpreted as collective dismissal costs or other exit costs since firms lack an additional margin of adjustment given that they cannot employ more than one worker. Although this is a quite restrictive assumption, it is a useful first step to convey the message as simple as possible before analyzing numerically interactions between product and labor market regulation for multiple-worker firms in future research. Moreover, collective dismissal costs are an important component of EPL (see OECD, 1999). In order to identify product and labor market regulation in the simplified modeling structure, we assume that the firm can fire and rehire without having to pay the set-up cost again.

We obtain the following results analyzing two scenarios. First we assume that workers transfer a downpayment to the firm so that firing costs do not exert a negative effect on entry because the firm is compensated ex ante. We show that set-up costs increase the scope for firing cost because firms can bear higher firing cost ex post without closing down. Second we relax the assumption of a downpayment so that firing costs negatively affect entry. We show in such a setting that set-up costs increase the benefits of firing costs for incumbent workers. This is because product market regulation decreases employment and thus the outside option of workers: once fired, it becomes more difficult to become reemployed so that the asset value of an unemployed worker falls.

The model closest to this paper is the one by Blanchard and Giavazzi (2003). ${ }^{1}$ Instead of focussing on the bargaining power of workers in the wage setting rule and its interaction with

\footnotetext{
${ }^{1}$ Ebell and Häfke (2003) extend the model to a fully dynamic framework and provide quantitative results on the wage and employment effects. Of course, interactions between product market rents and wage setting have been analyzed already before. E.g., Dowrick (1989) investigates the effect of rents in the product market on union bargaining. However, in Dowrick's static model the number of firms and the threat points are exogenous.
} 
product market competition, we analyze the interactions of product market regulation and firing costs abstracting from wage effects. Moreover, in the politico-economic analysis we explicitly take into account the general equilibrium feedbacks effects through changes of the number of firms. Most importantly, our explanation does not rely on the mechanism that product market regulation increases static rents in the job of which workers want to appropriate more. Interestingly, it is not even clear from a theoretical perspective that product market regulation increases rents in real terms as shown by Blanchard and Giavazzi (2003): regulation implies higher consumer prices and if this effect is strong enough it can more than outweigh the nominal wage increase. In our model, wages are exogenous ex post (in the downpayment case the wage bill is flexible ex ante) and the complementarity between firing and entry costs results from the effect of regulation on the dynamic rents: regulation decreases the number of jobs which makes the workers' outside option relatively worse.

Opposite to what we find in our paper, Amable and Gatti (2001) show in a dynamic efficiencywage model that firing costs should increase if product markets become more competitive. In their model firing costs counterbalance the negative employment effect resulting from higher turnover in a more competitive environment. However, the model's predictions are opposite to the empirical cross-country evidence presented above.

The following three politico-economic papers are related to our research. Belot (2002) or Hassler et al. (2002) argue that employment protection or social insurance are lower in the US than in continental Europe because mobility costs are higher in Europe. We propose another mechanism related to product market regulation. More closely related are the papers by Saint-Paul (2002) and Vindigni (2002) who show that higher firing costs result if more rents are appropriable in the economy. This is also the case in our model. However, rather than focussing on the static rents we analyze the effect of regulation on the dynamic rents which are endogenously determined.

The rest of the paper is structured as follows. In Section 2 we present the model of the product and labor market. In Section 3 we solve for the economic equilibrium before we discuss politicoeconomic considerations in Section 4. We conclude in Section 5. 


\section{The Model}

The economy is populated by $H$ ex ante identical agents. The agents are assumed to be risk neutral and earn wage $w$ if employed. Furthermore, we assume that the discount rate is equal to the interest rate and agents consume their income in every period. This is consistent with the assumption of risk neutrality in a general equilibrium context. Moreover, the assumption of risk neutrality allows us to focus on the interaction of rents and regulation in the labor and product market. Because of risk neutrality, wasteful firing costs redistribute rents among agents but decrease aggregate welfare. Hence, we abstract from additional dimensions of employment protection which arise when agents are risk averse. In this case employment protection can be a substitute for insurance in incomplete markets and increase aggregate welfare (see, e.g., Bertola (2003)).

\subsection{The Product Market}

The product market is modelled as a slight modification of the standard monopolistic competition model. As in Blanchard and Giavazzi (2003) or Peretto (2000) we assume that the elasticity of substitution between goods increases with the number of firms. Assume that the final good $Y$ is produced with $N$ intermediate goods $X_{i}$ according to the production function

$$
Y=N^{\frac{1}{1-\varepsilon}}\left(\sum_{i=1}^{N} X_{i}^{\frac{\varepsilon-1}{\varepsilon}}\right)^{\frac{\varepsilon}{\varepsilon-1}} .
$$

Aggregate demand $Y^{D}(P)$ ensures that the market for the final good clears. ${ }^{2}$ Each intermediate good is produced by one firm that uses one worker. We assume that the workers employed to produce the intermediate goods demand a negligible share of the final good so that changes in the price of the final good do not affect the real wage of the worker (we further discuss this assumption

\footnotetext{
${ }^{2}$ Note that in our model a larger number of firms implies that the final good is produced with more intermediate goods. I.e., implicitly the production technology changes. However, the finite number of industries allows us to explicity derive how the elasticity of product demand depends on $N$. Moreover, note that aggregate output does not increase with $N$ because of the factor $N^{\frac{1}{1-\varepsilon}}$ in equation (1).
} 
below). Producers of the final good solve the maximization problem

$$
\max _{X_{i}} P Y-\sum_{i=1}^{N} P_{i} X_{i}
$$

s.t. equation (1). It follows that the demand for the intermediate good is

$$
X_{i}=\left(\frac{P_{i}}{P}\right)^{-\varepsilon} \frac{Y}{N}
$$

and the elasticity of demand for each good is

$$
\eta(N) \equiv\left|\frac{\partial X_{i}}{\partial P_{i}} \frac{P_{i}}{X_{i}}\right|=\varepsilon-(\varepsilon-1) N^{-1}
$$

where $P_{i}$ is the price set by firm $i$ and

$$
P=\left(N^{-1} \sum_{i=1}^{N} P_{i}^{1-\varepsilon}\right)^{\frac{1}{1-\varepsilon}}
$$

Note that there are two effects that make the elasticity of demand depend on the number of firms. On the one hand there is a positive externality because the firm is able to pass on part of its price increase to all other firms. On the other hand there is also a negative externality because aggregate demand falls as the aggregate price $P$ increases. The positive externality will always be stronger, however, as long as prices are set optimally, i.e., $\varepsilon>1$.

We will also refer to $\eta(N)$ as degree of competition. As is intuitive, if $N \rightarrow \infty$, the effect of one firm's price setting does no longer matter for the aggregate and the elasticity converges to $\varepsilon$. Moreover,

$$
\frac{\partial \eta}{\partial N}=(\varepsilon-1) N^{-2}>0
$$

if $\varepsilon>1$ which holds in the optimum and

$$
\frac{\partial^{2} \eta}{\partial N^{2}}=-2(\varepsilon-1) N^{-3}<0
$$

Equations (2) and (3) imply that competition increases as more firms produce in the economy, but competition increases at a decreasing rate. 
Given that each firm in the intermediate good sector employs one worker, monopoly pricing implies that profit flows are given by (because all firms are symmetric we drop the index $i$ subsequently)

$$
\pi(N)=\frac{\eta(N)}{\eta(N)-1} w-w=\frac{1}{\eta(N)-1} w
$$

where $\eta /(\eta-1)$ is the standard markup over marginal cost $w$. Note that the markup decreases in $N$ so that

$$
\frac{\partial \pi}{\partial N}<0
$$

and

$$
\frac{\partial^{2} \pi}{\partial N^{2}}>0
$$

Equations (5) and (6) are important for understanding the interaction between product market regulation and firing costs below in the case of no downpayments. Higher firing costs decrease the number of firms in equilibrium so that profit flows rise and firms again break even. However, equations (5) and (6) imply that this effect is relatively less important if the number of firms is already small, e.g., because of product market regulation. Interestingly, empirical studies indeed tend to find that entry barriers which decrease the number of firms are positively correlated with profitability (see, e.g., Schmalensee's (1989) survey of the literature).

Contrary to Blanchard and Giavazzi (2003) we assume that product market regulation does not have an effect on the worker's price for consumption. This is plausible if the worker's industry is considered small relative to the aggregate or if the consumption bundle contains a substantial amount of imported goods. We employ this assumption because wages are exogenous in our model and thus workers do not obtain a share of the higher profits in more regulated markets. Thus, workers would always prefer flexible product markets because of lower prices. Blanchard and Giavazzi show that product market regulation makes workers worse off in real terms if wages are endogenous and the price increase of the final good resulting from regulation is fully passed on to 
the consumption price index. This is because in their model workers do not appropriate the full share of the rents, but have to bear the full cost of the price increase. Hence, in general it depends on the size of the two effects whether workers gain or loose in real terms when product markets are more regulated. Although it is important to bear this potential effect of product market regulation in mind, we abstract from it in this paper for simplicity. Below we will discuss further how allowing for a price effect influences the results of the paper.

\subsection{The Labor Market}

The labor market is assumed to be perfectly competitive. The unemployed earn the flow $\phi$ whereas workers earn the wage $w$. We assume that $w>\phi$, i.e., employment implies rents for the workers. We assume that the size of the static rent $w-\phi$ is exogenous in order to focus on the dynamic rents for incumbent workers, i.e., the difference between the asset value of employment and unemployment, $W-U$. In general, however, firing costs create a hold-up problem (see, e.g., Caballero and Hammour (1997)) so that workers are able to bid up wages once they are employed. E.g., with Nash bargaining wages of incumbent workers would be determined as

$$
w=(1-\beta) \phi+\beta(\zeta+r F)
$$

where $\beta$ is the bargaining power of the worker, $\zeta$ are the firm's revenues, $r$ is the market interest rate and $F$ is the firing cost (see, e.g., Mortensen and Pissarides (1999)). Instead, we assume that such rents exist without modeling this explicitly. This is not because it would be conceptually difficult to incorporate endogenous wages in our model, but to focus on a particular mechanism. We will mention below how endogenous wages would affect the results.

Firms Firms in the intermediate-good sector have to pay a set-up cost $C$ to enter the market. This set-up cost can be thought of as sunk cost such as red-tape which is shown to be relevant empirically by Fonseca et al. (2001) or Nicoletti et al. (2001). Firms can close down without cost if no worker is employed. Once a firm has entered the market it will always find it optimal to employ 
a worker. Denote with $J$ the asset value of the job. Every job is exposed to lump-sum profit shocks $a$ which arrive with Poisson probability $\lambda$. The profit shocks can be thought of as random government subsidies. ${ }^{3}$ The assumption of lump-sum profit shocks is useful because it allows us to introduce a stochastic environment while preserving that firms set their prices symmetrically as in the standard monopolistic competition model. We assume that the shocks $a$ are uniformly distributed according to the cumulated distribution function $G(a)$ in the interval $[-1,1]$ so that the expected value is 0 . Given these assumptions, the firm will close down with probability $\frac{1+R}{2}$ where the endogenous reservation value $R$ will be determined below. It follows that the asset value of the job $J$ is

$$
r J(a)=\pi+a+\lambda\left(\int_{R}^{1} J(y) d G(y)-\frac{1+R}{2} F-J(a)\right) .
$$

Applying the method of undetermined coefficients, this equation can be solved for $J$ :

$$
J(a)=\frac{\pi}{r+\lambda \frac{(1+R)}{2}}+\frac{a}{r+\lambda}+\frac{\lambda}{2} \frac{(1+R)^{2}}{(2 r+\lambda(1+R))(r+\lambda)},
$$

where we use equation (11) below to substitute for $F$.

Firms hire a worker if

$$
J(0) \geq 0
$$

and fire the worker if

$$
J(R) \leq-F
$$

We assume that firing costs are pure waste. ${ }^{4}$ Subtracting equations (9) and (10) using equation (8) we get that

$$
-\frac{R}{r+\lambda}=F
$$

\footnotetext{
${ }^{3}$ The subsidies are assumed to be financed lump-sum so that they do not distort behavior.

${ }^{4}$ If firing costs were pure transfers from the firm to the worker, firing costs would be neutral as long as wages are flexible (see, e.g., Lazear (1990) for a competitive model and Mortensen and Pissarides (1999) for a model with search frictions).
} 
which establishes the existence of a simple, downward-sloping, linear relationship between $R$ and $F$. Note that here the assumption becomes important that firms do not incur the set-up cost again if they fire and reemploy a worker.

In order to determine the number of firms we need to specify the asset value of the firm $V$. It is necessary to distinguish between the asset value of the firm and of the job to identify set-up costs from the firing costs by allowing firms to rehire a worker without incurring the set-up cost again. Firms incur the set-up costs only if they enter the market. All firms in the market that destroy a job, immediately create a new one as long as they remain in business since $J(0) \geq 0$. It follows that before the lump-sum shock realizes the number of jobs is equal to the number of firms $N$. Ex post, of course, some firms decide to destroy the job if the shock takes a value below the reservation value $R$. We need some exogenous churning to avoid corner solutions by guaranteeing that firms exit and enter in equilibrium. The asset value of the firm is

$$
r V(a)=r J(a)+\xi(-F-V(a))
$$

where $\xi$ is the exogenous probability that the firm goes out of business. Because the joint event of firing and churning is of second order which we neglect considering small time intervals, firms incur the firing costs when they exit the market for exogenous reasons. The entry and exit condition for firms are

$$
V(0) \geq C
$$

and

$$
V(0) \leq 0
$$

respectively. ${ }^{5}$ Using equation (8) and (11), we can spell out $V(0)$ :

$$
V(0)=\frac{r}{r+\xi}\left(\frac{2 \pi(N)}{2 r+\lambda(1-(r+\lambda) F)}+\frac{\lambda}{2} \frac{(1-(r+\lambda) F)^{2}}{(2 r+\lambda(1-(r+\lambda) F))(r+\lambda)}\right)-\frac{\xi}{r+\xi} F
$$

which is a function of $F$ and $N$.

\footnotetext{
${ }^{5}$ In the case of a downpayment $D>0$, the entry condition modifies to $V(0)+D \geq C$. We discuss the downpayment case in a separate subsection below where we derive an explicit expression for $D$.
} 
Remark 1: $V(0)$ decreases in $N$ and $F$.

Proof: see the Appendix.

Note that

$$
\frac{\partial^{2} V(0)}{\partial N \partial F}<0 \text { and } \frac{\partial^{2} V(0)}{\partial N^{2}}>0
$$

where the second inequality follows from equation (6).

To develop some more intuition it instructive to consider two special cases:

i) $r=0$ :

$$
\frac{\partial V(0)}{\partial F}=-1
$$

Because $r=0$, agents value the future as much as the present. Since firing costs are borne by the firm with certainty at some point in time, the value of the firm $V$ decreases by the same amount the firing cost increases. Note, however, that $r=0$ is not a very realistic case since firms need to receive a set-up subsidy $C=-F$ in order to enter the market.

ii) $\lambda=0$ :

$$
\frac{\partial V(0)}{\partial F}=-\frac{\xi}{r+\xi}
$$

If $\lambda=0$, firms incur firing costs only because $\xi>0$. Hence, at the margin firing costs decrease the value of the firm by $\xi$ which is the expected value of firing cost resulting from natural turnover and is discounted by the effective discount rate $r+\xi$.

Workers The asset value of being employed, $W$, and unemployed, $U$, can be written as

$$
r W=w+\left(\lambda \frac{1+R}{2}+\xi\right)(U-W)
$$

and

$$
r U=\phi+\left(\lambda \frac{1+R}{2}+\xi\right) \frac{N}{H-N}(W-U)
$$


Because there are no frictions in the labor market, fired workers immediately find another job if there is full employment in the economy, i.e., if $H=N$. Note that exogenous churning $\xi$ affects the number of available jobs for the unemployed since other firms will immediately enter and substitute for the number of exited firms so that $V(0)=C$ holds.

\section{The Economic Equilibrium}

A policy mix $(F, C)$ determines the economic equilibrium $(N, R)$ by the following two equations which we repeat for convenience:

$$
R=-(r+\lambda) F
$$

and

$$
V(0)=C \text {. }
$$

Given these equilibrium conditions, Remark 1 implies the following result.

Result 1 (No Downpayment) The equilibrium number of firms, $N$, and thus also the degree of competition $\eta(N)$, decrease in set-up costs $C$ and firing costs $F$.

Proof: see the Appendix.

The negative effect of product market regulation on the number of firms and employment is well supported empirically (see, e.g., Nickell (1999), Fonseca et al. (2001) or Bertrand and Kramarz (2002)). Moreover, firing costs negatively affect competition because they have a negative effect on entry. The negative effect of firing costs on employment, however, critically depends on the assumption that each firm only employs one worker. This result is specific to collective dismissal costs or other exit costs and does not hold in an environment in which firms employ more than one worker and face costs of marginal adjustment.

We now want to analyze the dependence of the economic equilibrium on the policy mix in two different scenarios. In the first scenario, Result 1 does not apply because unemployed workers can 
"buy" a job transferring a downpayment to the firm. In this case firing costs do not affect the number of firms in equilibrium and the outside option $U$. This scenario isolates the interaction between product and labor market regulation resulting from the fact that firms earn higher rents. In the second scenario we do not require that workers make a downpayment. In this scenario, Result 1 applies and set-up costs and firing costs have a negative effect on the outside option $U$ : it becomes more difficult for the worker to find another job if he is fired so that employment protection legislation implies an endogenous cost.

\subsection{Downpayment}

We assume that unemployed workers can buy a job transferring a downpayment to the firm. The downpayment implies that the wage bill is flexible ex ante. Workers exploit the fact that the entry cost $C$ is sunk and that firms will only close down if $V(0)<0$ once they have employed the worker: incumbent workers drive up firing cost until the firm is just indifferent whether to close down or not so that $V(0)=0$ after the firm has entered the market. Firms anticipate the workers' behavior and given that workers compete for jobs, firms will not enter the market unless the worker pays at least $C$ in order to compensate the firm for the entry cost.

Because there is perfect competition among workers, workers are indifferent between being employed or unemployed in equilibrium. Firms can extract all the worker's expected rents. The downpayment $D$ implies that the asset value of being unemployed reads

$$
U=\phi / r+\left(\lambda \frac{1+R}{2}+\xi\right) \frac{N}{H-N}\left[\frac{W-U}{r}-\frac{D}{r}\right]=\frac{\phi}{r} .
$$

The downpayment cannot be larger than $W-U$ because otherwise an unemployed worker would not accept to take up work. The expected rents of the worker have to be large enough to cover the set-up $\operatorname{cost} C$, i.e.,

$$
C \leq D=W-U=\frac{w-\phi}{r+\left(\lambda \frac{1+R}{2}+\xi\right) \frac{H}{H-N}},
$$

where we use equations (16) and (17). In equilibrium this condition holds with equality so that transfers ex ante offset the redistributive effects of firing costs ex post as noted, e.g., by Mortensen 
and Pissarides (1999). The modified entry condition in the downpayment case

$$
V(0)+D=C
$$

determines the number of firms $N$ where both $V(0)$ and $D$ decrease in $N$ (see Remark 1 and equation (18)). In equilibrium the downpayment makes unemployed workers indifferent whether to increase $F$ or not because $U=\phi / r$ so that unemployment is voluntary. Incumbent workers, instead, have an interest to increase firing costs in order to protect the rents. Given that the outside option $U$ remains unchanged, equation (16) implies that

$$
\frac{\partial W}{\partial F}=\frac{r+\lambda}{2} \frac{\lambda(w-\phi)}{\left(r+\lambda \frac{1-(r+\lambda) F}{2}+\xi\right)^{2}}>0
$$

if $w>\phi$. The gain from increasing firing costs is higher the lower the effective discount rate and the larger the rents, $w-\phi$. The latter is consistent with the fact that the generosity of unemployment insurance (a larger $\phi$ ) is negatively related to the strictness of EPL across continental European countries (see, e.g., Boeri et al. (2003)).

\section{Result 2 (Downpayment) Higher set-up costs $C$ increase the scope for firing costs $F$.}

Proof: see the Appendix.

The larger are the set-up costs $C$, the larger is the firm's inaction range implied by the entry and exit condition. This is exploited by incumbent workers but firms can undo this redistribution if unemployed workers compete for jobs and transfer their expected rents to the firm. Incumbent workers like higher setup costs $C$ because these increase the scope for firing costs to secure the rents ex post, or more precisely the maximal attainable $F$. Indeed, incumbent workers would have an incentive to increase $C$ to $C^{\prime}, C^{\prime}>C$, in order to increase $F$ subsequently: incumbent workers do not have to bear the cost of the higher downpayment $C^{\prime}$ but benefit from the higher rents in the market. Of course, this incentive is bounded since higher set-up costs decrease the number of firms in equilibrium and the number of firms is bounded below. Note that unemployed workers are indifferent because the outside option $U$ is unaffected by assumption. 


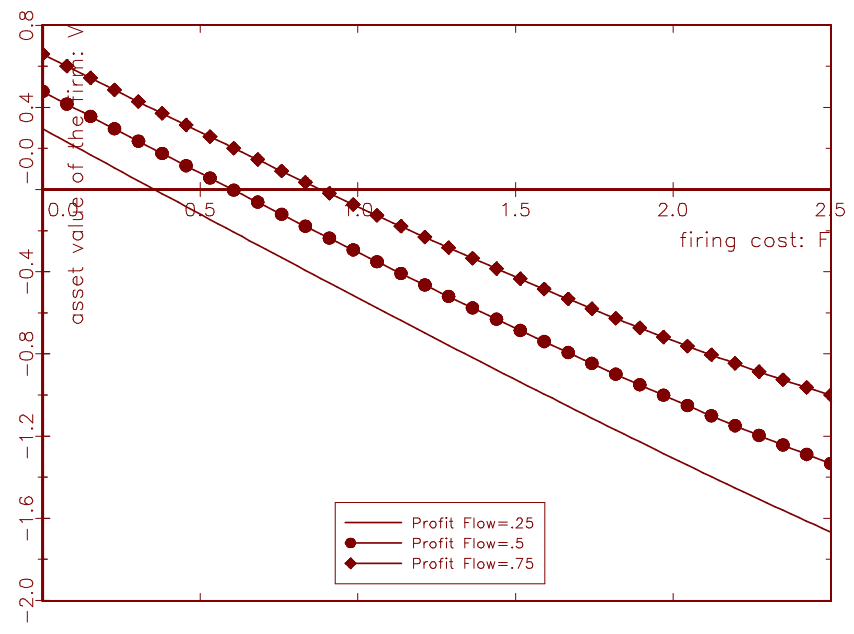

Figure 2: The asset value of the firm ex post, gross of the downpayment, as a function of firing costs for different profit flows.

We illustrate Result 2 numerically by plotting the asset value of the firm ex post, gross of the downpayment, as a function of firing costs for different profit flows (note that if the firm's asset value included the downpayment, the asset value would be equal to $C$ for all $F$ ). The parameter values are chosen to illustrate the solution as clear as possible and not necessarily for realism: $r=.15$, $\xi=.6$, and $\lambda=.25$. Figure 2 illustrates that $V(0)$ is monotonically decreasing in $F$. Moreover, higher set-up costs increase equilibrium profit flows so that the firing costs increase which make the firm indifferent whether to exit or not. Note that if $F=F_{\max }, R=-1$ so that firms never fire the worker unless they close down for exogenous reasons. Since $F_{\max }=(r+\lambda)^{-1}$,

$$
\left.V(0)\right|_{F=F_{\max }}=\frac{\pi-\xi(r+\lambda)^{-1}}{(r+\xi)},
$$

which can be read off at the right end of the graph. Furthermore, note that in Figure 2 the differences between the asset values of the firm for different profit flows are magnified as the firing cost increases: firms earn these profit flows relatively longer since they close down with a smaller probability.

The assumption of a downpayment allowed us to isolate the direct effect of rents on firing 


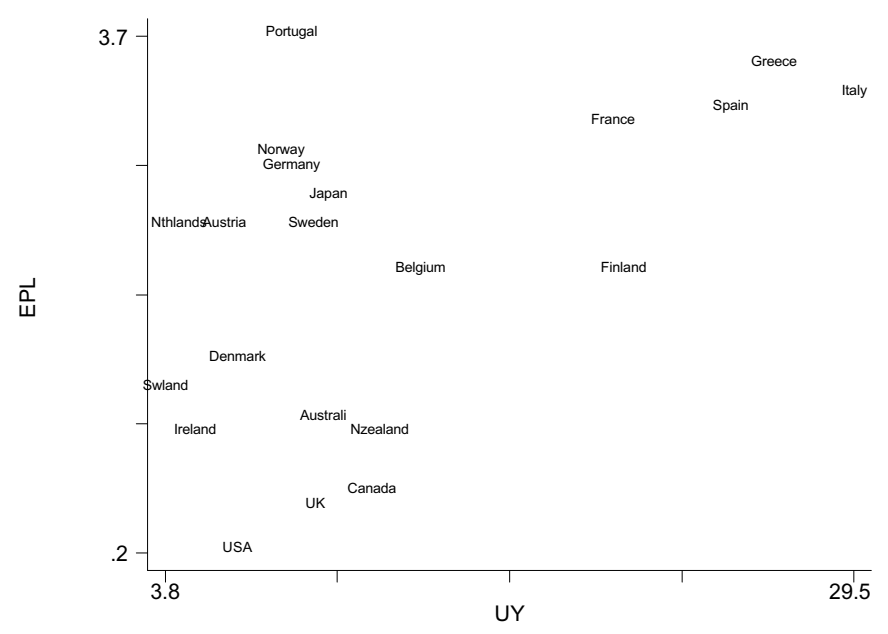

Figure 3: Employment protection legislation and youth unemployment. Source: The EPL indicator is taken from Nicoletti et al. (1999) as in Figure 1. The data for youth unemployment (age 20-24) as a percentage of the labour force, UY, is taken from OECD (2002), Table 1.6a.

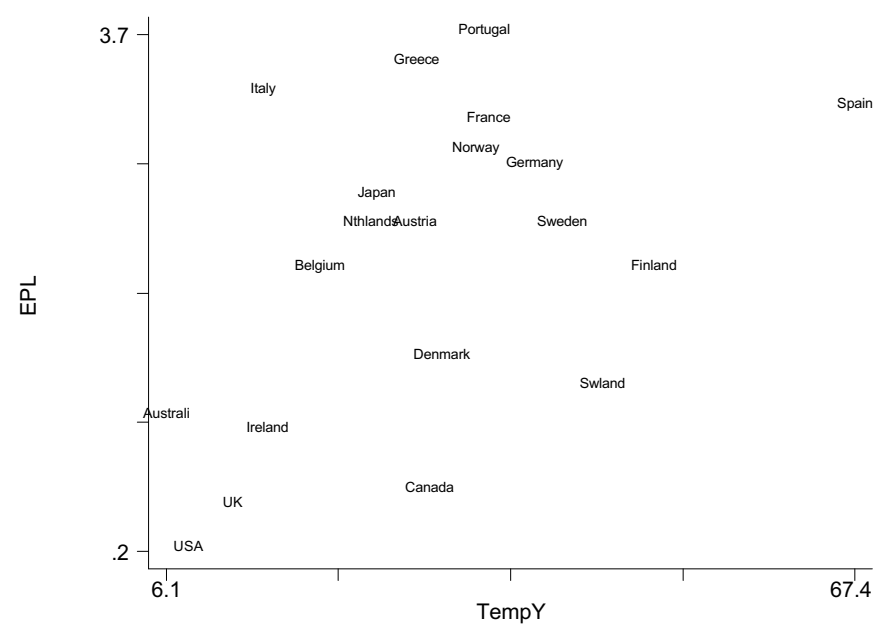

Figure 4: Employment protection legislation and temporary employment of young adults. Source: The EPL indicator is taken from Nicoletti et al. (1999) as in Figure 1. The data for temporary employment of young adults (age 15-24) as a percentage of young adults in employment, TempY, is taken from OECD (2002), Table 3.3. 
costs. Although the assumption is useful from a modelling perspective, it is far from realistic taken at face value. High downpayments of workers are not observed in reality and wages tend to be downward rigid in the same countries that have strict employment protection (see, e.g., Bertola and Rogerson (1997)). However, labor market entrants in countries with strict EPL are more likely to be unemployed, or conditional on employment are more likely to have a temporary contract. Figures 3 and 4 display these positive and significant correlations for young adults. ${ }^{6}$ Thus, downpayments do not seem unrealistic if interpreted more loosely as transfer of value-added in-kind or fringe benefits, from the worker to the firm.

\subsection{No Downpayment}

In the second scenario we do not require that workers make a downpayment. In this case Result 1 has shown that the number of firms $N$ is smaller the higher the firing costs $F$ : higher firing costs decrease the value of the firm so that competition needs to fall for firms' profits to increase sufficiently to make the equilibrium condition $V(0)=C$ hold again. We will now show how firing costs affect the outside option $U$ of workers. Because downpayments are not possible, unemployment is no longer voluntary and the asset value of the unemployed is defined by equation (17). We can solve for $W$ and $U$ as a function of $N$ and $R$ so that

$$
U=\frac{\phi}{r}+\frac{w-\phi}{r} \frac{\left(\lambda \frac{1+R}{2}+\xi\right) \frac{N}{H-N}}{r+\left(\lambda \frac{1+R}{2}+\xi\right) \frac{H}{H-N}}
$$

and

$$
W=\frac{w}{r}-\frac{w-\phi}{r} \frac{\left(\lambda \frac{1+R}{2}+\xi\right)}{r+\left(\lambda \frac{1+R}{2}+\xi\right) \frac{H}{H-N}} .
$$

Equations (19) and (20) decompose the asset values into the present discounted value if the employment state were permanent and the change of the asset value which depends on the turnover in the labor market.

\footnotetext{
${ }^{6}$ Note that temporary contracts do not include those working as free lancer. This possibly explains the low fraction of temporary jobs among young adults in Italy which has quite strict EPL.
} 
Remark 2 (No Downpayment) The asset value of the unemployed, $U$, positively depends on $N$ and negatively on $F$ (holding $N$ constant). The asset value of the employed, $W$, positively depends on $N$ and $F$ (holding $N$ constant).

Proof: see the Appendix.

Both, the unemployed and employed workers are better off if more firms produce in equilibrium: unemployed workers find another job relatively quicker which also increases the asset value of an employed. For this reason $W$ and $U$ negatively depend on the unemployment rate $u$, where $u \equiv(H-N) / H$ and $N /(H-N)=u^{-1}-1$. Instead, firing costs lower the turnover of jobs in the economy, $\lambda(1+R) / 2+\xi$, because the reservation value $R$ falls at which firms fire. This makes the unemployed worse off because the probability of finding a job is lower. Workers instead benefit from firing costs: the direct effect of earning the rents relatively longer outweighs the indirect effect of a lower outside option. The effect vanishes if there is full employment, $H=N$, because $U=W=w / r$ in this case: workers instantaneously find a new job once they are fired so that there is no scope for employment protection (Note, however, that this would not necessarily be the case if firing costs had a positive effect on wages).

We now analyze the benefits and costs of employment protection for incumbent workers. We define the benefit as the direct effect of firing costs on the asset value of the employed worker, $W$, whereas the cost is defined as the general equilibrium effect of firing costs on the number of firms.

Result 3 (No Downpayment) Incumbent workers benefit relatively more from firing costs if set-up or firing costs are high.

Proof: see the Appendix.

The intuition is that more regulation in product or labor markets decreases the number of firms $N$. As shown in Remark 2 this decreases the outside option of incumbent workers and results in a stronger incentive to protect the status quo. ${ }^{7}$

\footnotetext{
${ }^{7}$ The fact that lower turnover and worse reemployment prospects increase workers' benefit derived from employment protection is noted in a different context by Saint-Paul $(1995,1997)$.
} 
Let us now turn to the costs of employment protection where we assume that workers anticipate the general equilibrium effect of firing costs on the number of firms.

Result 4 (No Downpayment) The costs of employment protection fall the higher the set-up costs $C$.

Proof: see the Appendix.

The intuition is that profits decrease but at a decreasing rate (see equations (5) and (6)). Hence, in a relatively flexible economy with a large number of firms, $N$ has to fall relatively more after an increase of $C$ for the entry condition $V(0)=C$ to be satisfied.

It is important to note that the costs of EPL are not necessarily small for workers if $\frac{\partial N}{\partial F}$ is small. Empirically, the employment effects of EPL seem to be small (see, e.g., OECD (1999)). It then depends on the size of $\frac{\partial W}{\partial N}$ whether the cost of EPL is substantial or not. We will provide a numerical illustration below after having presented the political economy setup.

\section{Politico-Economic Considerations}

We focus on the case of no downpayment (the downpayment case yields qualitatively the same results to the analysis of unions with short-run interest below). Moreover, we focus on the role of incumbent workers who decide on $F$ for a given $C$. As we have shown in Remark 2 unemployed workers are worse off with labor as well as product market regulation. Hence, the complementarity between product and labor market regulation observed in reality crucially depends on incumbent workers who are the only ones benefiting from employment protection. We assume that the workers' representative chooses firing costs that maximize the sum of workers' welfare, i.e.,

$$
\max _{F} N W
$$

This implies that the workers' lobby does not care about the unemployed as in insider models of unions. Unfortunately, the empirical evidence on this matter is rather inconclusive (see, e.g., the 
survey of Lever and van Veen (1991)). We consider the assumption a useful starting point. The first-order condition of the maximization problem is

$$
\frac{\partial N}{\partial F}\left(W+N \frac{\partial W}{\partial N}\right)+N \frac{\partial W}{\partial F}=0
$$

Given Results 3 and 4 this first-order condition implies that the scope for employment protection increases if product markets are more regulated. The scope of employment protection is defined as the interval of $F$ for which the left-hand-side of equation (21) is weakly positive.

Result 5 (No Downpayment) Set-up costs increase the scope for firing costs.

Proof: see the Appendix.

We now illustrate Result 5 numerically. Table 1 displays the parameter values which are chosen as an example rather than necessarily for realism.

Table 1: Parameter Values

\begin{tabular}{ll}
\hline \hline$r=.15$ & $\varepsilon=3$ \\
$\lambda=.25$ & $w=.5$ \\
$\xi=.6$ & $\phi=0$ \\
$H=N$ if $F=.5 ; C=.1$ & \\
\hline \hline
\end{tabular}

We assume full employment for the flexible economy with the lowest firing costs and product market regulation, i.e., $H=N$ if $F=.5$ and $C=.1 .^{8}$

In the plot of the necessary condition in Figure 5 firing costs decrease welfare for incumbent workers if set-up costs are small: the necessary condition is always negative for $C=.1$. However, more regulated product markets make firing costs less of a bad deal: as shown analytically in Result 5, the necessary condition shifts upward as set-up costs increase. Since the necessary condition

\footnotetext{
${ }^{8}$ For an interior solution we need that $F>0$ and/or $C>0$. If $F=C=0$, there exists no number of firms $N$ so that $V(0)=0$. This is because the effect of exogenous churning, which guarantees an interior solution, vanishes as $F \rightarrow 0$
} 


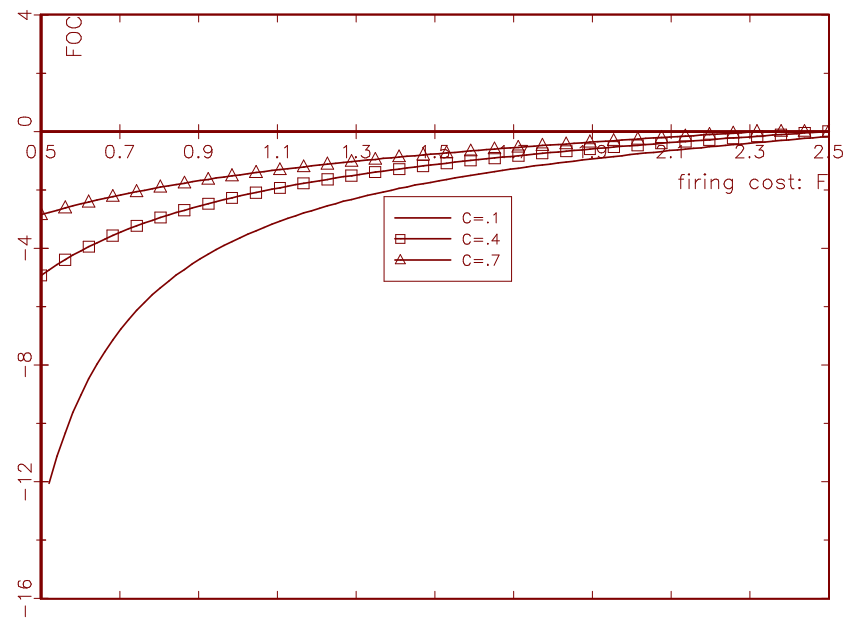

Figure 5: The necessary condition as a function of $F$ for different $C$

increases in $F$, the optimal $F^{*}=F_{\max }$ if the necessary condition is weakly positive for some $F$. Indeed, $F^{*}=F_{\max }$ if $C=.4$ and $C=.7$ but $F^{*}=0$ for $C=.1$. As mentioned above, for high $C$ and $F$ the general equilibrium effect $\partial N / \partial F$ becomes negligibly small. The costs of EPL become less important whereas the benefits of EPL increase.

Having shown that our simple model can explain the positive correlation between EPL and PMR, we now discuss the robustness of the results. First we adapt our model to analyze what happens if the worker's lobby neglects or heavily discounts the general equilibrium effect. Second we discuss other factors that are important but outside our model.

Unions with short-run interest In this subsection we characterize the politico-economic equilibrium if unions discount the general equilibrium effects heavily. Indeed, the general equilibrium effects might need a long time to work themselves out so that in present-discounted terms they can be neglected (exogenous exit and resulting entry take time for the economy to reach the new equilibrium. As assumed in Blanchard and Giavazzi (2003), $N$ might be given in the short run and flexible only in the long run). To adapt our model in the simplest possible way we assume that 


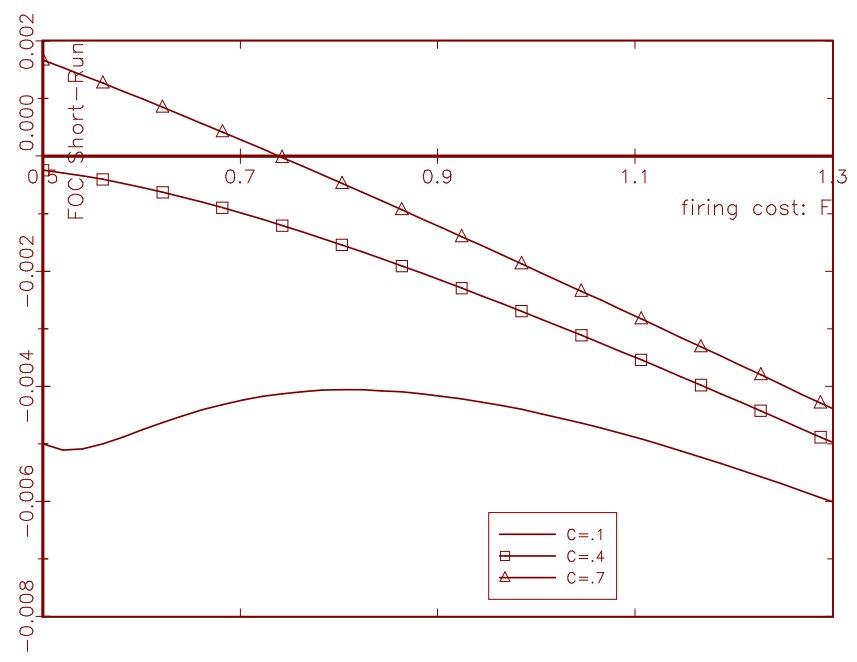

Figure 6: The union with short-run interest: the first-order condition as a function of $F$ for different $C$

there is a quadratic cost for lobbying so that unions maximize

$$
\max _{F} N W-\frac{1}{\kappa} F^{2} .
$$

The first-order condition is

$$
\left.N \frac{\partial W}{\partial F}\right|_{N}-2 \kappa^{-1} F=0
$$

which we plot in Figure 6 for $\kappa=200$.

Note that the necessary condition decreases in $F$ unless we consider the range of parameters in the vicinity of $F=.5$ and $C=.1$ where we assume $H=N$ so that $\partial W / \partial F \mid N$ increases from zero to a positive number. The negative slope of the necessary condition in Figure 2 implies that the optimal $F^{*}$ is determined by the first-order condition. The optimal firing cost increases if the product market is more regulated (a higher $C$ ): $F^{*}>0$ only for $C=.7$. The intuition is straightforward given Result 3. 
Extensions We now want to discuss three extensions of the model where the first two are related: endogenous price and wage effects resulting from changes in competition, and risk aversion.

i) endogenous price effects

If we allow changes in competition to affect the workers' consumption price index $P_{c}$, EPL and product market regulation imply an additional cost. Both decrease the equilibrium number of firms so that competition falls and the markup increases. Assume that changes in competition are fully passed on to the consumption price index. From equation (4) we know that the markup $m$ is

$$
m \equiv\left(1-\eta(N)^{-1}\right)^{-1} .
$$

It follows that

$$
\frac{\partial m}{\partial N}=-\frac{\partial \eta(N)}{\partial N}(\eta(N)-1)^{-2}<0
$$

since $\partial \eta(N) / \partial N>0$ as shown in equation (2). Given this property of the markup, the cost of regulation increases because $\partial W / \partial P_{c}<0$ and $\partial P_{c} / \partial N<0$. The results mentioned above remain qualitatively the same.

ii) endogenous wage effects

Assuming that wages are exogenous is a strong assumption which is only justified to simplify the model. Endogenous wages, however, do not change necessarily the qualitative insights of the simpler model. In order to make this point, assume that wages are determined by Nash bargaining as already mentioned above:

$$
w=(1-\beta) \phi+\beta(\zeta(N)+r F) .
$$

Recall that $\beta$ is the bargaining power of the worker and $\zeta$ are the firm's revenues which are a decreasing function of $N$. Both set-up cost $C$ and firing cost $F$ increase nominal wages because $d N / d C<0$ and $d N / d F<0$ (as shown in Result 1): revenues $\zeta$ increase of which workers obtain a share. Moreover, firing costs increase wages directly because they create a hold-up problem that increases workers' bargaining power ex post (see, e.g., Mortensen and Pissarides (1999) or 
Caballero and Hammour (1997)). Hence, more regulation, be it in the labor or product market, increases the nominal rents of incumbent workers and thus also the costs of EPL in terms of the general equilibrium effect on the number of firms. The reason is that more regulation decreases the equilibrium number of firms and increases revenues because of the lower competition. But part of this increase is passed on to workers so that profits increase more slowly and the general equilibrium effect $d N / d C$ or $d N / d F$ is amplified. Moreover, $\partial W / \partial N$ can increase if one allows for both endogenous wages and prices. One the one hand there is an additional negative effect of competition on nominal wages. On the other hand competition decreases prices so that the real wage can very well increase with $N$ as long as the worker's share of revenues $\beta$ is smaller than the rate of pass-through to consumption prices (see Blanchard and Giavazzi (2003)). In this case, endogenous wage and price effects increase the costs of regulation $(\partial W / \partial N) d N / d F$ and decrease the benefits $\left.\frac{\partial W}{\partial F}\right|_{N}$ since real wages of incumbent workers fall. Hence, endogenous wages and prices per se do not explain necessarily the complementarity between EPL and PMR. However, if one allows changes in competition to affect the elasticity of labor demand, Spector (2002) shows that product market regulation can make workers better off. Less competition decreases the elasticity of labor demand and strengthens the bargaining position of workers. To sum up, endogenous wages and prices introduce a number of additional effects with opposite signs. Whether product market regulation increases or decreases real rents and thus the incentive of workers to protect such rents depends on the assumptions about the relative strength of the effects.

iii) risk aversion

Assuming that workers are risk neutral, we have abstracted from additional dimensions of employment protection which arise when agents are risk averse. In this case employment protection can be a substitute for insurance in incomplete markets (see, e.g., Bertola, 2003). The insurance motive increases the benefits derived from EPL. Moreover, such insurance will be particularly desirable if labor or product markets are already regulated. This is because labor turnover is relatively low in regulated markets and agents can poorly self-insure themselves in incomplete financial markets if unemployment spells are long (see, e.g., Deaton (1992), ch. 6, on the ineffectiveness of buffer-stock 
saving for persistent income shocks). Indeed, the more severe the financial market imperfection, the more agents prefer less turnover (see Bertola and Koeniger, 2003). Hence, risk aversion of workers has the potential to explain why unions lobby more for EPL if regulated product markets increase unemployment duration.

\section{Conclusions and Further Research}

We have shown that workers lobby more for employment protection if product markets are more regulated. More regulation decreases employment so that the outside option of workers becomes worse. This strengthens the incentive of incumbent workers to protect their job. From a policy perspective this is particularly relevant for the EU. If the recent deregulation of product markets results in employment gains, introducing more flexibility in the labor market should become relatively easier from a politico-economic perspective.

To be more confident about the results, it is necessary to allow for multiple-worker firms although the solution will only be obtainable numerically. This gives firms an additional margin of adjustment and renders both the analysis of employment protection and product market regulation more meaningful. Moreover, in our model a crucial determinant of the outcomes is the status quo of regulation. Indeed, workers have little interest to increase firing costs if there is full employment in the economy; and workers do not benefit necessarily from product market regulation if the decrease in competition feeds back into higher consumption prices. Thus, it might seem puzzling how countries end up with heavy regulation. One possibility is that exogenous shocks in a model with multiple equilibria have resulted in different outcomes for otherwise similar countries (see, e.g., Hassler et al. (2002) for a model along these lines explaining differences in labor market regulation across countries). In this paper we have taken another route by arguing that differences in product market regulation are determined by differences in fundamentals between Anglo-Saxon and continental European countries, such as differences in enforcement of anti-trust laws (see La Porta et al. (1998) for more details on the differences in the judicial system between Anglo-Saxon 
common-law and continental European civil-law countries). We have shown that these differences in product market regulation endogenously induce different incentives for regulation in the labor market. More research is needed to better understand how and why countries differ substantially in terms of regulation. 


\section{Appendix}

\section{Proof of Remark 1:}

Taking partial derivatives of equation (14) we get,

$$
\frac{\partial V(0)}{\partial N}=A \frac{\partial \pi}{\partial N}<0,
$$

where

$$
A \equiv \frac{r}{r+\xi} \frac{1}{r+\lambda \frac{1-(r+\lambda) F}{2}}
$$

and the inequality follows because $\partial \pi / \partial N<0$ (see equation (5)). The partial derivative $\partial V(0) / \partial F$ (holding $N$ constant) is

$$
\begin{aligned}
\frac{\partial V(0)}{\partial F} \propto & \lambda(r+\lambda) C+\frac{\lambda \xi(r+\lambda)}{r(r+\xi)} F-\frac{\lambda^{2} r}{2} \frac{(1-(r+\lambda) F)^{2}}{(2 r+\lambda(1-(r+\lambda) F))(r+\xi)} \\
& -\frac{\lambda r}{r+\xi}(1-(r+\lambda) F)+\frac{\lambda^{2} r}{2(r+\xi)}(1-(r+\lambda) F)^{2}-\frac{\xi}{r+\xi}(2 r+\lambda(1-(r+\lambda) F)),
\end{aligned}
$$

where we have substituted $\pi(N)$ using the entry condition (12). This expression is messy and not very insightful but it is immediate that

$$
\frac{\partial V(0)}{\partial F}<0 \text { if } C<C^{*},
$$

where $C^{*}$ is implicitly determined by the equation $\partial V(0) / \partial F=0$. Note that this condition is sufficient but not necessary. Heuristically, there are two opposing effects at work: on the one hand firing costs decrease turnover and let firms earn profits relatively longer. On the other hand, firing costs directly decrease the asset value of the firm since laying off the worker becomes more costly. The latter effect has to dominate the former as long as firing costs have some bite. There is no externality in the model that firing costs alleviate so that the constraint of firing costs decrease the asset value of the firm.

\section{Proof of Result 1:}

The entry condition (12) and Remark 1 imply that

$$
\frac{d N}{d C}=[\partial V(0) / \partial N]^{-1}<0
$$


and

$$
\frac{d N}{d F}=-\frac{\partial V(0) / \partial F}{\partial V(0) / \partial N}<0
$$

Given equation (2), it immediately follows that $\eta$ decreases.

\section{Proof of Result 2:}

The maximal firing costs attainable for workers are implicitly determined by the equation $V(0)=0$. Implicit differentiation of the exit condition implies

$$
\frac{d F}{d C}=-\frac{\frac{\partial V(0)}{\partial N}}{\frac{\partial V(0)}{\partial F}} \frac{\partial N}{\partial C}>0,
$$

where use the fact that in the downpayment case $\partial N / \partial F=0$. The positive sign follows from Remark 1 and Result 1

\section{Proof of Remark 2:}

Taking partial derivatives of equations (19) and (20) and using equation (11), we get

$$
\begin{gathered}
\frac{\partial U}{\partial N}=\frac{w-\phi}{r}\left(\lambda \frac{1+R}{2}+\xi\right) H \frac{r+\lambda \frac{1+R}{2}+\xi}{\left(r(H-N)+\left(\lambda \frac{1+R}{2}+\xi\right) H\right)^{2}}>0, \\
\frac{\partial U}{\partial F}=-(r+\lambda) \frac{w-\phi}{r} N \lambda \frac{\left(r(H-N)+\left(\lambda \frac{1+R}{2}+\xi\right)(H-N)\right)}{2\left(r(H-N)+\left(\lambda \frac{1+R}{2}+\xi\right) H\right)^{2}}<0, \\
\frac{\partial W}{\partial N}=\frac{w-\phi}{r} \frac{\left(\lambda \frac{1+R}{2}+\xi\right)^{2} \frac{H}{(H-N)^{2}}}{\left(r+\left(\lambda \frac{1+R}{2}+\xi\right) \frac{H}{H-N}\right)^{2}}>0, \\
\frac{\partial W}{\partial F}=(w-\phi) \frac{(H-N)^{2}(r+\lambda) \frac{\lambda}{2}}{\left(r(H-N)+\left(\lambda \frac{1+R}{2}+\xi\right) H\right)^{2}}>0,
\end{gathered}
$$

if $w>\phi$ and $H>N$. For $H=N$,

$$
\frac{\partial W}{\partial F}=0
$$


and

$$
\frac{\partial W}{\partial N}=\frac{(w-\phi)}{H} \frac{\lambda \frac{1+R}{2}}{r\left(\lambda \frac{1+R}{2}+\xi\right)} .
$$

\section{Proof of Result 3:}

Using the partial derivative derived in Remark 2, we can show that

$$
\frac{\partial^{2} W}{\partial F^{2}}=2(w-\phi) \frac{\left(\frac{H-N}{H}(r+\lambda) \frac{\lambda}{2}\right)^{2}}{\left(r \frac{H-N}{H}+\left(\lambda \frac{1+R}{2}+\xi\right)\right)^{3}}>0,
$$

holding $N$ constant, and

$$
\frac{\partial^{2} W}{\partial F \partial N}=-(w-\phi) H \frac{(H-N)(r+\lambda) \lambda\left(\lambda \frac{1+R}{2}+\xi\right)}{\left(r(H-N)+H\left(\lambda \frac{1+R}{2}+\xi\right)\right)^{3}}<0,
$$

if $w>\phi$ and $H>N$.

The second cross-derivative implies that

$$
\frac{\partial^{2} W}{\partial F \partial C} \geq 0
$$

given that $\frac{d N}{d C}<0$ as shown in Result 1 .

\section{Proof of Result 4:}

Using Result 1 we can write the costs of employment protection for incumbent workers as

$$
\frac{\partial W}{\partial N} \frac{d N}{d F}=-\frac{\partial W}{\partial N} \frac{\partial V(0) / \partial F}{\partial V(0) / \partial N}<0 .
$$

Using the partial derivatives derived in Remark 1 and 2 we can show that

$$
\begin{gathered}
\frac{\partial^{2} W}{\partial N^{2}}=\frac{w-\phi}{r} H \frac{r\left(\lambda \frac{1+R}{2}+\mu+\xi\right)^{2}}{\left(r(H-N)+\left(\lambda \frac{1+R}{2}+\mu+\xi\right) H\right)^{3}}>0, \\
\frac{\partial^{2} V(0)}{\partial N \partial F}=-\frac{r}{r+\xi} \frac{\lambda \frac{(r+\lambda)}{2}(1-r)}{\left(r+\lambda \frac{1-(r+\lambda) F}{2}\right)^{2}} \frac{\partial \pi}{\partial N}<0
\end{gathered}
$$


holding $N$ constant when taking the cross-derivative and

$$
\frac{\partial^{2} V(0)}{\partial N^{2}}=\frac{r}{r+\xi} \frac{1}{r+\lambda \frac{(1-(r+\lambda) F)}{2}} \frac{\partial^{2} \pi}{\partial N^{2}}>0
$$

since

$$
\frac{\partial^{2} \pi}{\partial N^{2}}>0
$$

Recalling from Remark 1 that $\partial V(0) / \partial F<0$ and $\partial V(0) / \partial N<0$, and $d N / d C<0$ from Result 1 , these partial derivatives imply that

$$
\partial\left|\frac{\partial W}{\partial N} \frac{d N}{d F}\right| / \partial C<0
$$

\section{Proof of Result 5:}

Note that if the left-hand side of equation (21) is positive agents prefer larger firing costs. Taking a partial derivative of the left-hand side of the first-order condition (21) with respect to $C$, we get

$$
\frac{\partial N}{\partial F \partial C}\left(W+N \frac{\partial W}{\partial N}\right)+2 \frac{\partial N}{\partial F} \frac{\partial N}{\partial C} \frac{\partial W}{\partial N}+N \frac{\partial N}{\partial F} \frac{\partial N}{\partial C} \frac{\partial^{2} W}{\partial N^{2}}+\frac{\partial N}{\partial C} \frac{\partial W}{\partial F}+N \frac{\partial W}{\partial F \partial C} .
$$

It remains to be shown that the expression has a positive sign. Note that the signs of the partial derivatives derived in the Remarks and Results above imply that

$$
\frac{\partial N}{\partial F \partial C}=-\frac{\frac{\partial^{2} V(0)}{\partial N \partial F} \frac{\partial V(0)}{\partial N}-\frac{\partial^{2} V(0)}{\partial N^{2}} \frac{\partial V(0)}{\partial F}}{\left(\frac{\partial V(0)}{\partial N}\right)^{2}} \frac{\partial N}{\partial C}>0 .
$$

The only negative term in expression $\left(^{*}\right)$ is $\frac{\partial N}{\partial C} \frac{\partial W}{\partial F}$. It is sufficient for expression $\left(^{*}\right)$ to be positive that the second term is larger than the fourth:

$$
-2 \frac{\partial N}{\partial F} \frac{\partial W}{\partial N}>\frac{\partial W}{\partial F}
$$

where we have divided by $\partial N / \partial C<0$. Using the first-order condition (21) we substitute

$$
\frac{\partial W}{\partial F}=-\frac{\partial N}{\partial F}\left(\frac{W}{N}+\frac{\partial W}{\partial N}\right)
$$


so that the condition can be rearranged to

$$
\frac{\partial W}{\partial N}>\frac{W}{N}
$$

This inequality is satisfied because, as shown in Result 4,

$$
\frac{\partial^{2} W}{\partial N^{2}}>0
$$




\section{References}

[1] Amable, Bruno and Donatella Gatti (2001): "Product Market Competition and Employment Protection: a Case for Policy Complementarity", mimeo.

[2] Belot, Michele (2002): "Why is the Employment Protection Stricter in Europe than in the US?", Tilburg University, mimeo.

[3] Bertola, Giuseppe (2003): "A Pure Theory of Job Security and Labor Income Risk", Review of Economic Studies, forthcoming.

[4] Bertola, Giuseppe and Winfried Koeniger (2003): "Consumption Smoothing and the Structure of Labor and Credit Markets", IZA, mimeo.

[5] Bertola, Giuseppe and Richard Rogerson (1997): "Institutions and Labor Reallocation", European Economic Review, vol. 41, 1147-71.

[6] Bertrand, Marianne and Francis Kramarz (2002): "Does Entry Regulation Hinder Job Creation? Evidence from the French Retail Industry", Quarterly Journal of Economics, vol. 117, $1369-414$.

[7] Blanchard, Olivier and Francesco Giavazzi (2003): "Macroeconomic Effects of Regulation and Deregulation in Goods and Labor Markets", Quarterly Journal of Economics, vol. 118, 879907.

[8] Boeri, Tito, J. Ignacio Conde-Ruiz and Vincenzo Galasso (2003): "Protecting Against Labor Market Risk: Employment Protection or Unemployment Benefits?", IZA Discussion Paper No. 834.

[9] Botero, Juan, Simeon Djankov, Rafael La Porta, Florencio Lopez-de-Silanes and Andrei Shleifer (2003): "The Regulation of Labor," NBER Working Paper No. 9756. 
[10] Caballero, Ricardo J. and Mohamad L. Hammour (1997): "The Macroeconomics of Specificity", Journal of Political Economy, vol. 106, 724-67.

[11] Deaton, Angus (1992): Understanding Consumption, Oxford University Press.

[12] Djankov, Simeon, Rafael La Porta, Florencio Lopez-de-Silanes, Andrei Shleifer (2002): "The Regulation of Entry", Quarterly Journal of Economics, vol. 117, 1-37.

[13] Dowrick, Steve (1989): "Union-Oligopoly Bargaining”, Economic Journal, vol. 99, 1123-42.

[14] Ebell, Monique and Christian Häfke (2003): "Product Market Deregulation and Labor Market Outcomes", Universitat Pompeu Fabra, mimeo.

[15] Fonseca, Raquel, Paloma Lopez-Garcia and Christopher A. Pissarrides (2001): "Entrepreneurship, Start-Up Costs and Employment", European Economic Review, vol. 45, 692-705.

[16] Hassler, John, Jose V. Rodriguez Mora, Kjetil Storesletten and Fabrizio Zilibotti (2002): “A Positive Theory of Geographic Mobility and Social Insurance", IIES, Stockholm University, mimeo.

[17] La Porta, Rafael, Florencio Lopez-de-Silanes, Andrei Shleifer and Robert W. Vishny (1998): "Law and Finance", Journal of Political Economy, vol. 106, 1113-55.

[18] Lazear, Edward P. (1990): "Job Security Provisions and Employment", Quarterly Journal of Economics, vol. 105, 609-726.

[19] Lever, Marcel and Tom van Veen (1991): "Union Wage Setting, Employment and Investment: a Survey of Theory and Empirical Evidence", Labour, vol. 5, 25-61.

[20] Mortensen, Dale and Christopher A. Pissarides (1999): "New Developments in Models of Search in the Labor Market", in: Handbook of Labor Economics, Ashenfelter, Orley and David Card (eds.), vol. 3B, North Holland, Amsterdam. 
[21] Nickell, Stephen (1999): "Product Markets and Labor Markets", Labor Economics, vol. 6, $1-20$.

[22] Nicoletti, Giuseppe, Stefano Scarpetta and Olivier Boylaud (1999): "Summary Indicators of Product Market Regulation with an Extension to Employment Protection Legislation", OECD Economics Department Working Papers No. 226, OECD, Paris.

[23] Nicoletti, Giuseppe, Robert C.G. Haffner, Stephen Nickell, Stefano Scarpetta and Gylfi Zoega (2001): "European Integration, Liberalization and Labor Market Performance", in: Welfare and Employment in a United Europe, Bertola, Giuseppe, Tito Boeri and Giuseppe Nicoletti (eds.), MIT Press, Cambridge, 147-235.

[24] OECD (1999): "Employment Protection and Labour Market Performance", Employment Outlook, ch. 2, OECD, Paris.

[25] OECD (2002): Employment Outlook, OECD, Paris.

[26] Orszag, Mike and Dennis J. Snower (1998): "Anatomy of Policy Complementarities", Swedish Economic Policy Review, vol. 5, 303-43.

[27] Peretto, Pietro F. (2000): "Market Power, Growth and Unemployment", Duke University, mimeo.

[28] Saint-Paul, Gilles (1995): "The High Unemployment Trap,", Quarterly Journal of Economics, vol. $110,527-50$.

[29] Saint-Paul, Gilles (1997): "The Rise and Persistence of Rigidities", American Economic Review, vol. 87, 290-4.

[30] Saint-Paul, Gilles (2002): "The Political Economy of Employment Protection", Journal of Political Economy, vol. 110, 672-704. 
[31] Schmalensee, Richard (1989): "Inter-Industry Studies of Structure and Performance", in: Handbook of Industrial Organization, Schmalensee, Richard and Robert D. Willig (eds.), vol. 2, North Holland, Amsterdam.

[32] Spector, David (2002): "Competition and the Capital-Labor Conflict", CEPREMAP-CNRS, Paris, mimeo.

[33] Vindigni, Andrea (2002): "Uncertainty and the Politics of Employment Protection", Discussion Paper No. 465, Princeton, Department of Economics - Industrial Relations Section. 


\section{IZA Discussion Papers}

\begin{tabular}{|c|c|c|c|c|}
\hline No. & Author(s) & Title & Area & Date \\
\hline 866 & A. Constant & $\begin{array}{l}\text { Immigrant Adjustment in France and Impacts on } \\
\text { the Natives }\end{array}$ & 1 & $08 / 03$ \\
\hline 867 & $\begin{array}{l}\text { T. J. Dohmen } \\
\text { B. Kriechel } \\
\text { G. A. Pfann }\end{array}$ & $\begin{array}{l}\text { Monkey Bars and Ladders: The Importance of } \\
\text { Lateral and Vertical Job Mobility in Internal } \\
\text { Labor Market Careers }\end{array}$ & 1 & $08 / 03$ \\
\hline 868 & $\begin{array}{l}\text { P. Brañas Garza } \\
\text { S. Neuman }\end{array}$ & $\begin{array}{l}\text { Analyzing Religiosity Within an Economic } \\
\text { Framework: The Case of Spanish Catholics }\end{array}$ & 5 & $08 / 03$ \\
\hline 869 & $\begin{array}{l}\text { A. B. Krueger } \\
\text { A. Mas }\end{array}$ & $\begin{array}{l}\text { Strikes, Scabs and Tread Separations: Labor } \\
\text { Strife and the Production of Defective } \\
\text { Bridgestone/Firestone Tires }\end{array}$ & 3 & $09 / 03$ \\
\hline 870 & $\begin{array}{l}\text { S. Klasen } \\
\text { A. Launov }\end{array}$ & $\begin{array}{l}\text { Analysis of the Determinants of Fertility Decline } \\
\text { in the Czech Republic }\end{array}$ & 4 & $09 / 03$ \\
\hline 871 & $\begin{array}{l}\text { Y. L'Horty } \\
\text { C. Rault }\end{array}$ & $\begin{array}{l}\text { The Impact of Growth, Labour Cost and Working } \\
\text { Time on Employment: Lessons from the French } \\
\text { Experience }\end{array}$ & 5 & $09 / 03$ \\
\hline 872 & $\begin{array}{l}\text { J. R. Munch } \\
\text { M. Rosholm } \\
\text { M. Svarer }\end{array}$ & Are Home Owners Really More Unemployed? & 1 & 09/03 \\
\hline 873 & $\begin{array}{l}\text { M. Falk } \\
\text { B. M. Koebel }\end{array}$ & $\begin{array}{l}\text { The Impact of Office Machinery and Computer } \\
\text { Capital on the Demand for Heterogeneous } \\
\text { Labour }\end{array}$ & 5 & $09 / 03$ \\
\hline 874 & J.-S. Pischke & $\begin{array}{l}\text { The Impact of Length of the School Year on } \\
\text { Student Performance and Earnings: Evidence } \\
\text { from the German Short School Years }\end{array}$ & 6 & $09 / 03$ \\
\hline 875 & C. Grund & $\begin{array}{l}\text { Severance Payments for Dismissed Employees } \\
\text { in Germany }\end{array}$ & 3 & 09/03 \\
\hline 876 & $\begin{array}{l}\text { M. Karanassou } \\
\text { H. Sala } \\
\text { D. J. Snower }\end{array}$ & $\begin{array}{l}\text { The European Phillips Curve: Does the NAIRU } \\
\text { Exist? }\end{array}$ & 3 & 09/03 \\
\hline 877 & M.-S. Yun & Decomposing Differences in the First Moment & 3 & 09/03 \\
\hline 878 & $\begin{array}{l}\text { J. T. Addison } \\
\text { C. Schnabel } \\
\text { J. Wagner }\end{array}$ & $\begin{array}{l}\text { The Course of Research into the Economic } \\
\text { Consequences of German Works Councils }\end{array}$ & 3 & 09/03 \\
\hline 879 & $\begin{array}{l}\text { A. Constant } \\
\text { Y. Shachmurove }\end{array}$ & $\begin{array}{l}\text { Entrepreneurial Ventures and Wage Differentials } \\
\text { Between Germans and Immigrants }\end{array}$ & 1 & 09/03 \\
\hline 880 & $\begin{array}{l}\text { W. Koeniger } \\
\text { A. Vindigni }\end{array}$ & $\begin{array}{l}\text { Employment Protection and Product Market } \\
\text { Regulation }\end{array}$ & 2 & $10 / 03$ \\
\hline
\end{tabular}

An updated list of IZA Discussion Papers is available on the center's homepage www.iza.org. 